\title{
Original Research \\ Changeability of Accumulated Heat Content in Alpine-Type Lakes
}

\author{
Adam Choiński ${ }^{1 *}$, Mariusz Ptak ${ }^{1}$, Agnieszka Strzelczak² \\ 'Institute of Physical Geography and Environmental Planning, Adam Mickiewicz University, \\ Dzięgielowa 27, 61-680 Poznan, Poland \\ ${ }^{2}$ Faculty of Food Sciences and Fisheries, West Pomeranian University of Technology in Szczecin, \\ Pawła VI 3, 71-459 Szczecin, Poland \\ Received: October 14, 2014 \\ Accepted: July 20, 2015
}

\begin{abstract}
This study presents the variation in the accumulated heat content of the alpine-type lake Morskie Oko in the highest mountain range of the Carpathians - the Tatras. The analysis was based on detailed water temperature measurements carried out in 2007 at the deepest site of the lake. Additionally, the changeability of heat content in 1973-2012 was assessed using measurements performed at one site near the shore at a depth of $0.4 \mathrm{~m}$. The highest and the lowest values of accumulated heat content were recorded in August and February, which is typical for lakes in intermediate latitudes. The monthly average accumulated heat content in the studied year amounted to $186,830 \mathrm{GJ}$. Long-term dynamics of heat content indicated an upward trend, particularly from the late 1990s, which was closely connected with an increase in air temperature. This investigation indicated that mountain lakes - commonly regarded as cool - may be a potential source of "clean" energy in hard-to-reach terrain (e.g., for the needs of mountain refuges, holiday camps, etc.).
\end{abstract}

Keywords: accumulated heat content, climate change, mountain lake, Tatra Mountains, water temperature

\section{Introduction}

Considerable accumulation of matter and energy is one of the features of lakes distinctive among various components of the natural environment. The energy accumulated in a lake can be expressed as the accumulated heat content. Its amount depends mainly on the climatic zone a water body is located in as well as on local conditions, morphometric features of a lake basin, the presence of contaminants, etc. Alpine lakes are a specific group of mountain lakes and their distinctiveness - particularly compared to lowland lakes located in the same latitude - has been studied by researchers of many scientific fields [1-5]. The commonly reported increasing trend in water temperature [6-9],

*e-mail: choinski@amu.edu.pl being the consequence of global climate warming, also concerns mountain lakes. As a result, they will undergo a considerable evolution [10].

The rising temperature contributes to the increase in the accumulated heat content observed in lake water and thus may alter physical, chemical, and biological processes. This has been underlined for example by [11], who confirmed that the course of some physical processes is closely dependent on the heat content accumulated in a lake. As a result, the transformations of mostly cool alpine aquatic ecosystems are highly probable [12] and will concern the changes in species composition of flora and fauna, the course of water overturn, the range of epilimnion, etc. The issue of observable and potential changes in respect to ichthyofauna have been discussed by [13, 14]. The aim of this study was to assess the amount of heat content accu- 
mulated in an alpine-type lake - Morskie Oko (Tatra Mountains, Carpathians, Fig. 1) - and to analyse its changes over a yearly and longer-term time period.

\section{Experimental Procedures}

The amount of accumulated heat content can be assessed base on the investigation of water temperature vertical profile combined with information on the lake morphometric parameters. Water temperature in this study was measured in 2007 using an A-STER temperature sonde RTW8 (Fig. 2) located at the deepest site in the centre of the lake $(51.8 \mathrm{~m})$.

Temperature data were saved automatically every 30 minutes at five depths: $1 \mathrm{~m}, 5 \mathrm{~m}, 10 \mathrm{~m}, 20 \mathrm{~m}$, and $50 \mathrm{~m}$. As a result, the whole dataset included 84,000 cases. Due to the considerable thickness of ice cover [15] there was a danger of sensor damage in the near surface water layer, therefore it was placed at a depth of $1 \mathrm{~m}$. Temperature sensors (type Pt-100, class $1 / 5 \mathrm{~B}$ ) were connected to the recorder with cables in a polyurethane isolation characterized by considerable resistance to environmental conditions. Data were transferred to a computer through a wireless connection using the RasterR program (dedicated to A-STER loggers).

The morphometric features of Morskie Oko are presented in Table 1.

Apart from the one-year study, long-term standardized observations (1973-2012) of water temperature in the nearsurface zone ( $0.4 \mathrm{~m}$ depth) were included in the investigation. They were conducted by the Polish National Institute of Meteorology and Water Management (IMGiW). Additionally, the air temperatures (average for 24 hours calculated from three measurements at 6 a.m., noon, and 6 p.m.) and the course of ice phenomena observed in 2007 were included in the analyses.
Table 1. Morphometric parameters of Lake Morskie Oko [16].

\begin{tabular}{|l|c|}
\hline \multicolumn{1}{|c|}{ Parameter } & Value \\
\hline Area [ha] & 33.39 \\
\hline Maximum depth [m] & 51.8 \\
\hline Average depth [m] & 29.7 \\
\hline Water volume [dam $\left.{ }^{3}\right]$ & $9,904.3$ \\
\hline Altitude [m a.s.l.] & $1,394.6$ \\
\hline
\end{tabular}

According to [17] the heat content accumulated in a lake can be calculated as the sum of heat contents in consecutive layers (e.g., zones between isobaths):

$$
q_{w}=t \cdot c \cdot \rho \cdot v[\mathrm{cal}]
$$

...where:

$q_{w}$ - accumulated heat content

$t$ - average water temperature of a layer of $v$ volume

$c$ - specific heat capacity of water

$\rho$ - water density

$v$ - volume of water layer

Assuming that $c=1$ and $\rho=1$, the equation can be written as follows:

$$
q_{w}=t \cdot v[\mathrm{cal}]
$$

Therefore, the total accumulated heat content can be determined according to the formula:

$$
Q=\Sigma t \cdot v[\mathrm{cal}]
$$

\section{Results}

The daily values of water temperature in Morskie Oko recorded in 2007 are presented in Fig. 3. It clearly shows

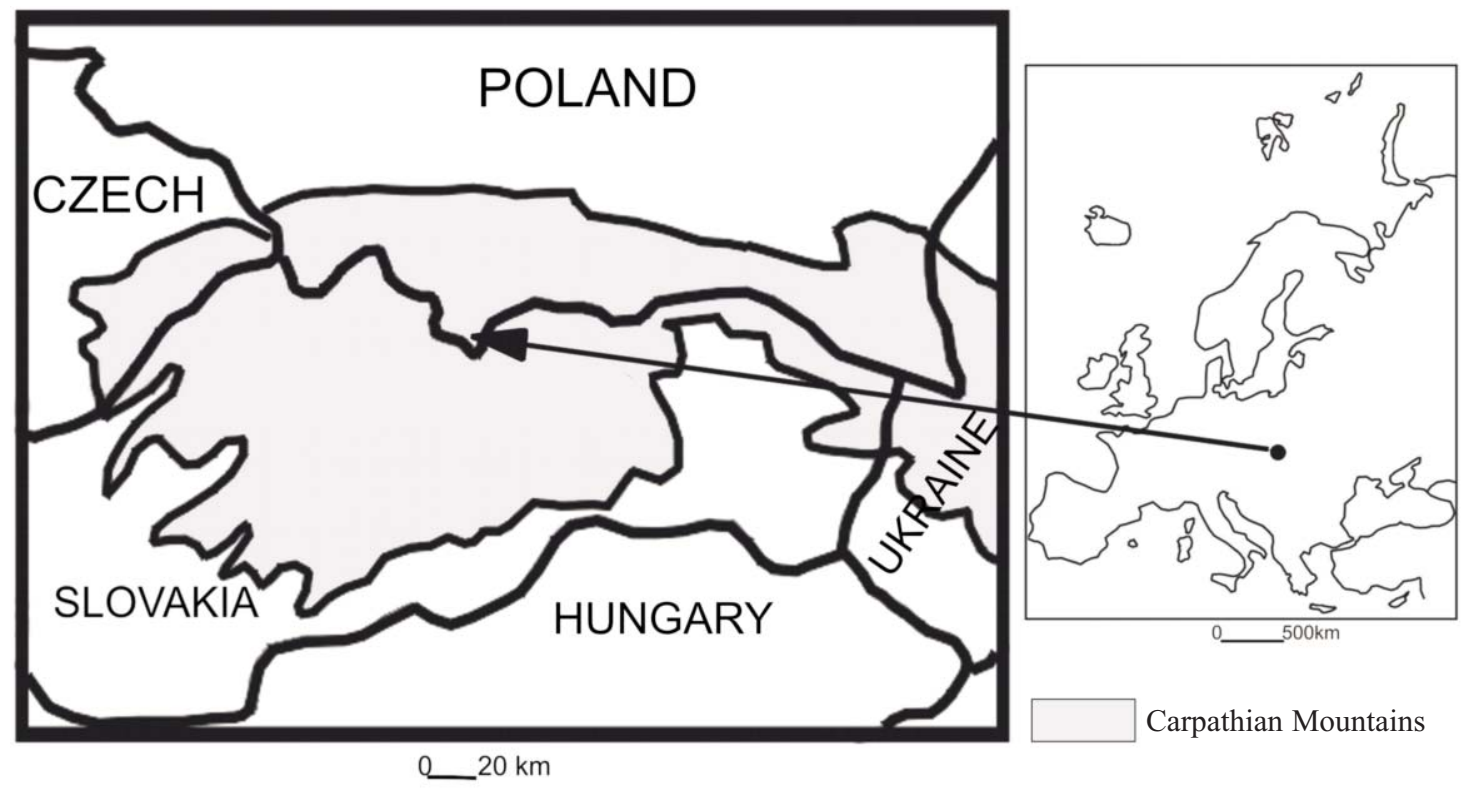

Fig. 1. Tatra Mountains in the Carpathians. 
a)

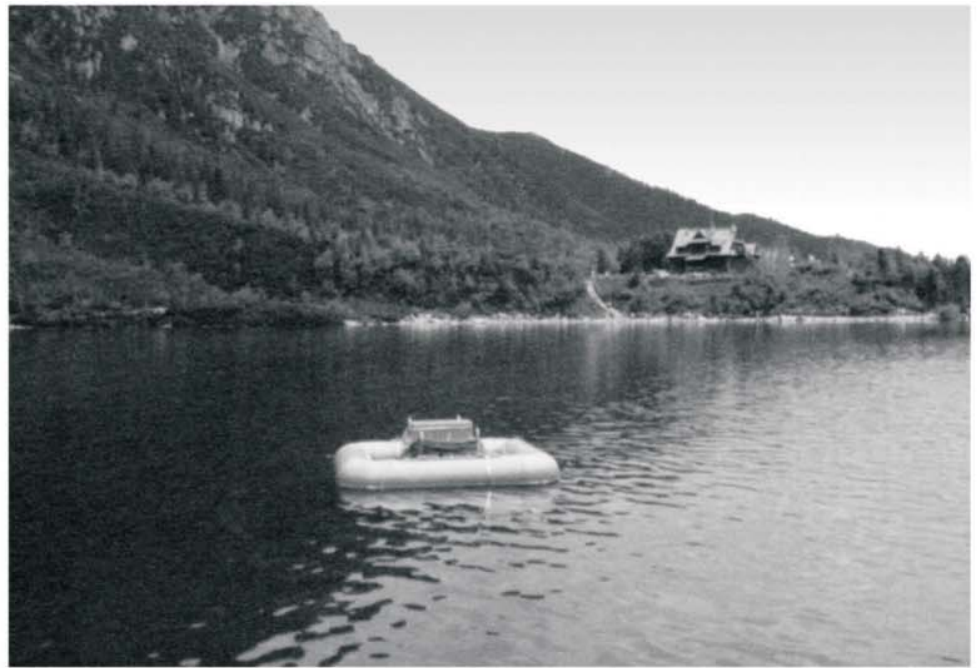

b)

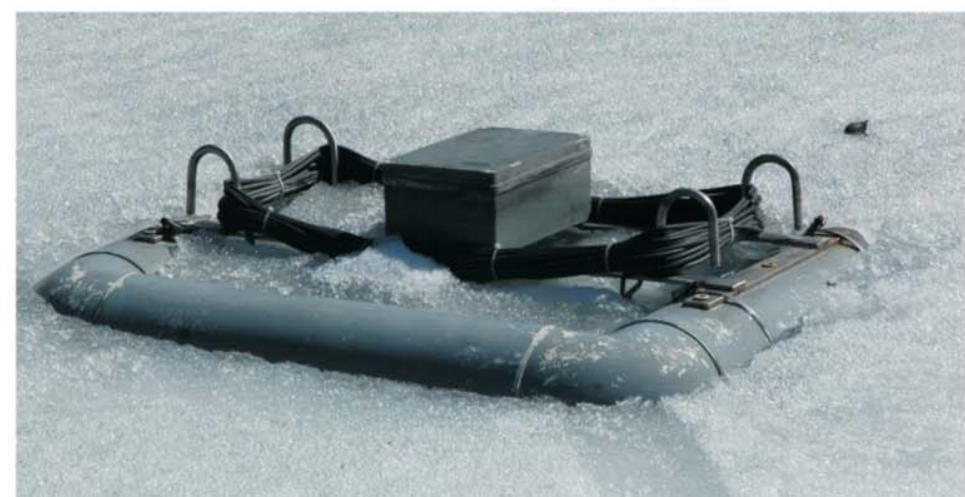

c)

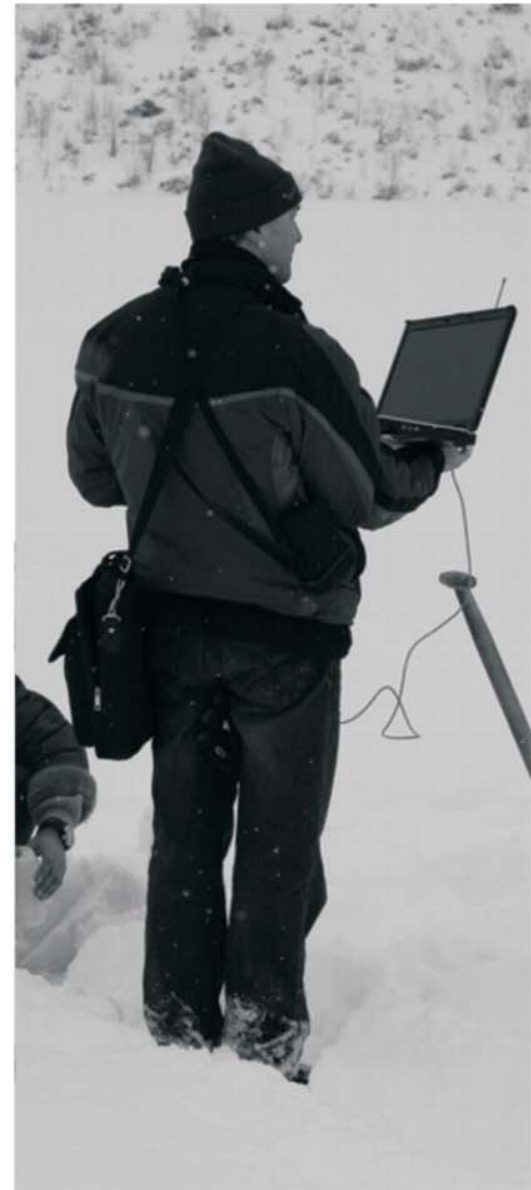

Fig. 2. Temperature sonde RTW 8 at the surface of Lake Morskie Oko: a) in summer, b) in winter, c) download of data in winter.

both seasonal and vertical dichotomy. After long-duration ice cover (it disappeared on 15 April), water gradually heated up and reached homothermy around 9 May. However, this state lasted for only a short time - until 14 May. Next, the typical stratification was observed, with the highest water temperature on 21 July at a depth of $1 \mathrm{~m}\left(15.2^{\circ} \mathrm{C}\right)$. After that, the gradual decrease in water temperature (with minor oscillations) was recorded leading to a period of homothermy (4-9 November) and followed by catothermy. Then on 9 November the ice cover formed and isolated water from external factors. It should be noted that distinct vertical changes in water temperature were observed down to a depth of $10 \mathrm{~m}$. The lower volume of water was isolated from the influence of external factors, mainly wind.

The monthly average values of water temperature in Morskie Oko were compared with air temperatures recorded at the IMiGW station located several dozen meters from the lake (Fig. 4). In turn, Fig. 5 shows the accumulated heat content.

The annual mean water temperature in Morskie Oko (calculated from all the depths studied) amounted to $4.7^{\circ} \mathrm{C}$. The monthly average water temperatures, except for the

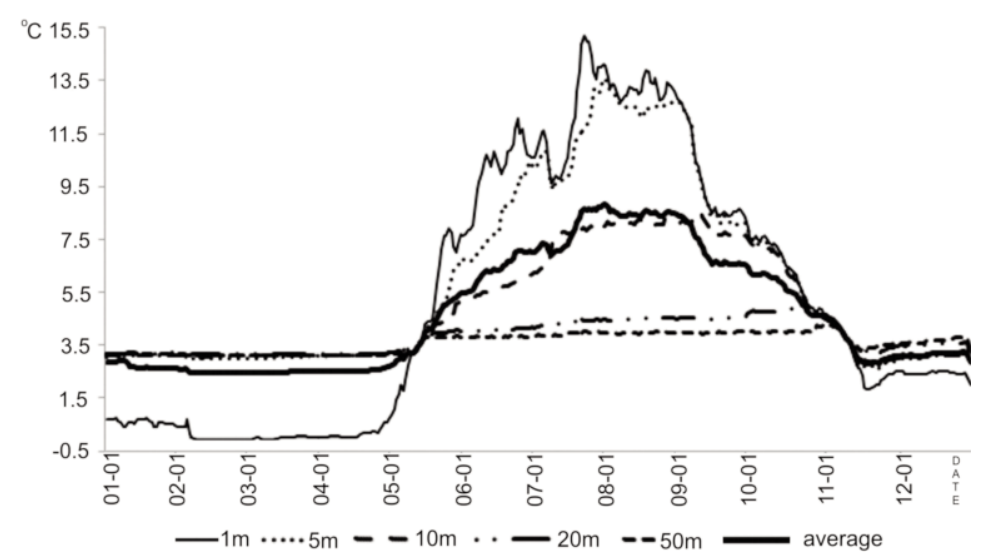

Fig. 3. Daily course of water temperature in Lake Morskie Oko in 2007 at consecutive depths. 


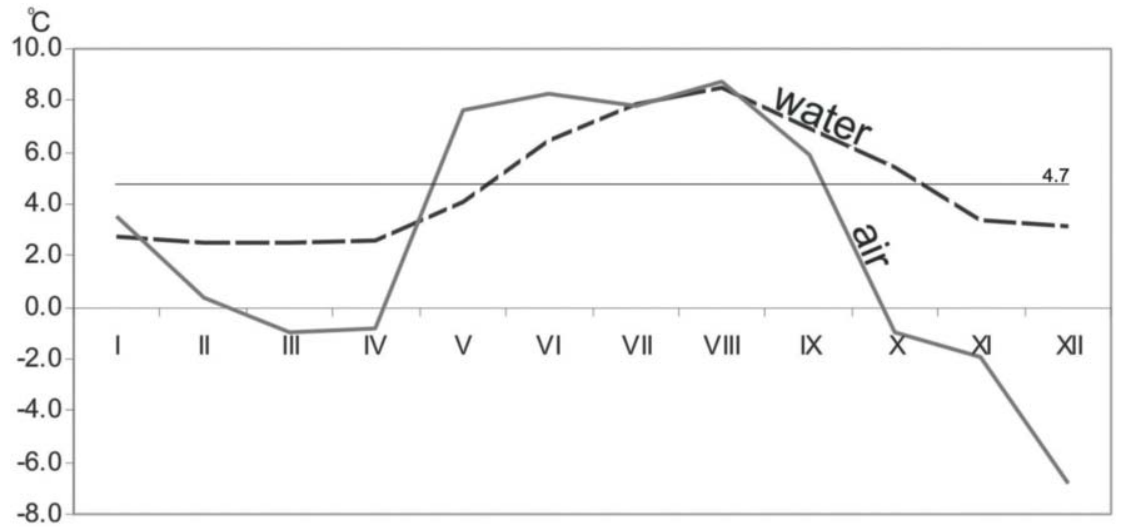

Fig. 4. Monthly average values of Lake Morskie Oko water temperature compared with air temperature recorded in the vicinity of the lake in $2007\left(4.7^{\circ} \mathrm{C}\right.$ - average value of water temperature for the whole year).

period between the disappearance of ice cover and middle August, were higher than air temperatures recorded only several dozen meters from the lake shore (Fig. 4).

Taking into account that water density and its specific heat capacity are constant values, the heat content accumulated in water is directly proportionate to water temperature. Thus, the highest accumulated heat content in Morskie Oko fell on August and amounted to 339,340 GJ. The difference between the highest and the lowest heat contents was almost 250,000 GJ. The amount of accumulated heat in August was over three-fold higher compared to the months when ice cover was present (January-April), with the lowest accumulation in February (99,380 GJ). The annual average accumulated heat content in 2007 was 186,830 GJ, which corresponded to 8,497 tons of carbon with calorific value of $0.022 \mathrm{GJ} \mathrm{kg}^{-1}$. The analysis of consecutive zones of Morskie Oko water volume allowed us to indicate that the annual average heat content accumulated in epilimnion ( $30 \%$ of the whole lake basin) was higher than in the remaining water volume by over 53,000 GJ. The biggest difference between epilimnion and the rest of the lake fell on August and amounted to 285,000 GJ.

At the next stage of the study, the long-term changes in the temperature of water in Morskie Oko were investigated (Fig. 6). The analysis unambiguously indicated the upward trend in the subsurface water temperature. The highest increase started in the 1990s, when the annual average water temperature exceeded the long-term mean value $\left(5.1^{\circ} \mathrm{C}\right)$.

\section{Discussion of Results}

Water is characterized by low thermal conductivity. The increase of water temperature is mainly the result of convection or mixing (waves, water currents). Morskie Oko, investigated in this study, has a considerable depth and is shielded by the high surrounding peaks of the Tatra Mountains. Therefore, that water body is an example of a meromictic lake, where only the subsurface water layer undergoes mixing during spring and autumn circulation. The influence of the lake surrounding heat accumulation has been discussed in the example of a water body in Florida [18]. The observations showed that the heat was not transferred to the deepest zones during thermal stratification as a result of the orographic barrier (vegetation around the lake) hampering wind circulation. The influence of orographic conditions on heat accumulation also has been thoroughly described for Lake Tekapo in New Zealand's southern alps [19].

The lack of a temperature sensor in the subsurface layer of the lake in this study might raise reservations. However, the temperature of epilimnion was measured at three depths: $1 \mathrm{~m}, 5 \mathrm{~m}$, and $10 \mathrm{~m}$ [20], based on the example of alpine lakes in Switzerland, where the temperature recorded at $5 \mathrm{~m}$ is representative of the whole epilimnion. In this context, the accumulated heat content for the epilimnion estimated in this study for three depths can be considered as reliable.

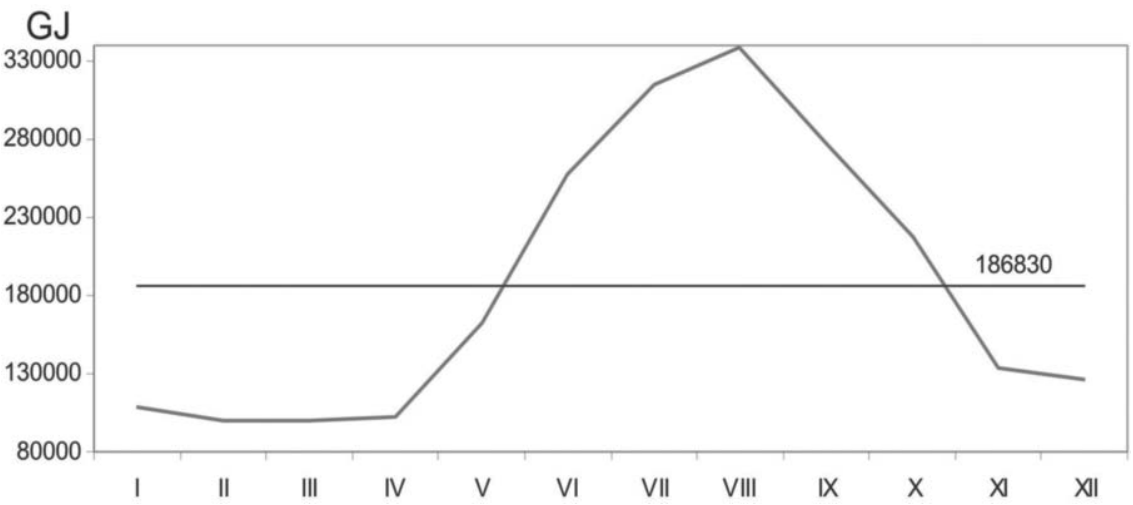

Fig. 5. Heat content accumulated in Lake Morskie Oko in 2007 (186,830 GJ - average value for the whole year). 
The highest and the lowest heat contents accumulated in Morskie Oko were recorded in August and February, consecutively. This is in accordance with the results obtained for other lakes located in middle latitude - both lowland $[21,22]$ and mountain water bodies [23].

Estimation of lake hydrologic budgets is essential for sustainable water management due to increasing water demand and uncertainties related to climate change [24]. Heat accumulated in lakes can be an alternative source of energy, which is particularly important against the background of decreasing fossil fuel supplies. Kanikowski [25] created a model that assessed the influence of heat consumption on the functioning of Zamkowe Lake (northern Poland). It turned out that the heat consumption at a level of $2 \mathrm{MW}$ would cool water by $0.07^{\circ} \mathrm{C}$ in one year. That value is considerably lower than the natural, annual oscillations in lake water temperature. However, some disturbances such as the lack of ice phenomena or rapid changes in thermal stratification can be observed at the sites of water intake and discharge. Taking into account that Morskie Oko is located within Tatra National Park and is therefore is under strict protection, the potential generation of power for economic purposes is out of the question. However, in the case of other mountain lakes located outside national parks, such a possibility should be considered as a source of "clean" energy, for example to supply mountain refuges or holiday camps.

Long-term observations of water temperature in the subsurface zone of Morskie Oko (Fig. 6) indicate an upward trend, which is consistent with observations from other regions of the world (as described in our introduction). The state of lakes is a good indicator of global climate change [26]. Forecasts concerning changes occurring in those water bodies indicate considerable changes in the functioning of alpine lakes [27]. Long-term changes in the heat content accumulated in Morskie Oko confirm those prognoses. The variations in the overall accumulated heat content over the years 1973-2012 can be assessed based on the average water temperature in 2007 (at the deepest site) and the long-term course of subsurface water temperature (recorded several meters from the lake shore). The highest accumulated heat content fell on year 2011 (around
195,000 GJ) and the lowest in 1982 (around 125,000 GJ). The difference between those two values is considerable and amounts to 70,000 GJ. It should be noted that since the late '90s the annual average heat contents were never below 160,000 GJ. Changes in the thermal dynamic of lake water volume, for instance, result in the shorter duration of ice cover or changes in water circulation [28]. The increasing heat accumulated in the water of Morskie Oko has also resulted in shorter ice cover duration - [29] assessed as having decreased by 10 days $\cdot \mathrm{dec}^{-1}$. The relationship between heat content and ice cover has been described in the example of Lake Pääjärvi in southern Finland [30]. Those data might be useful for further studies on processes determining lake dynamics. Such information is crucial for water management [31].

Phenomena and processes occurring in mountain lakes are specific compared to other lakes located at similar latitudes. They mainly depend on climate conditions and secondarily on individual features of water bodies as well as on the local environment. The fact that Morskie Oko is located on granite bedrock is crucial for its thermal conditions. This was visible in the comparison of water and air temperatures (Fig. 4). The summer period showed some anomaly since water temperature then was equal to - not lower than - air temperature.

The heating of granite rocks forming the lake bottom and shore causes an increase in water temperature even if there is no direct solar radiation at a given time. The rocks play the role of "storage" for heat. This is shown in the thermal photograph of Morskie Oko's surface (Fig. 7a).

The further from shore toward the deeper lake zone, the lower the role of heated rocks as water temperature considerably decreases at a short distance (Fig. 7b). Therefore, one can conclude that the distribution of isotherms in the central part of the lake was mainly influenced by wind conditions. That situation shows that individual features of alpine lakes may influence processes occurring in them more than global climate change. Moreover, there are also other important factors such as sunlight exposure and the shadowing of different parts of mountain water bodies, which have been reported by $[15,33,34]$.

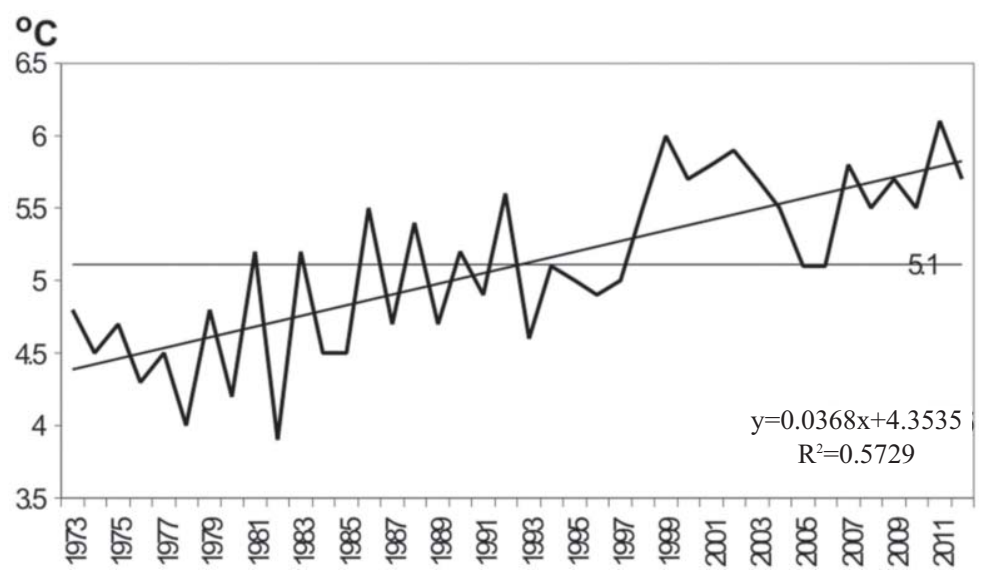

Fig. 6. The course of annual average water temperature in Lake Morskie Oko at a depth of $0.4 \mathrm{~m}$ under the lake surface, 1973-2012 $\left(5.1^{\circ} \mathrm{C}-\right.$ long-term mean value). 
a)

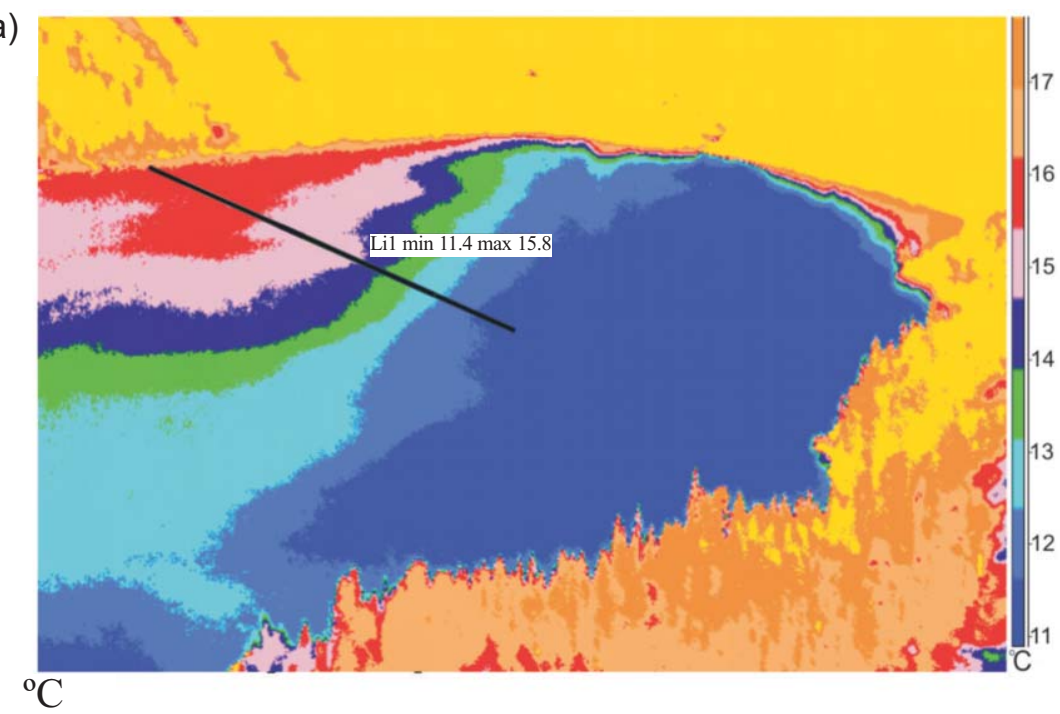

b)

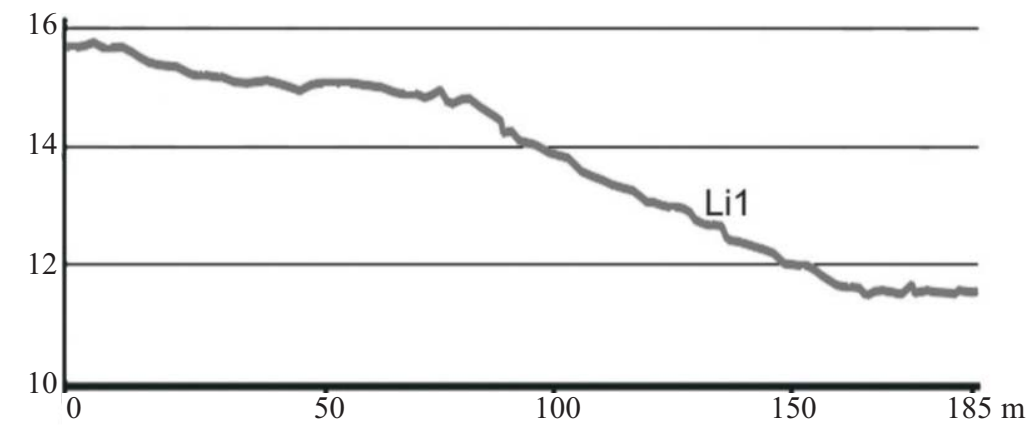

Fig. 7. Thermal characteristics of the northern part of Lake Morskie Oko's surface: a) thermal photograph taken at 4 pm on 11.IX.2012, b) distribution of water temperature along the Li1 profile [32].

\section{Conclusions}

Results presented in this study show that the heat accumulated in Morskie Oko is closely connected with the variation in water temperature (both seasonal and long-term), as well as with the morphometry of the lake:

1. Morskie Oko shows the most distinct dynamics of heat content in the epilimnion zone (down to around $10 \mathrm{~m}$ below surface).

2. One year's investigation indicated that the highest and lowest accumulated heat content occurred in August and February, respectively, which is typical of lakes (both mountain and lowland) located at middle latitudes.

3. The commonly observed global temperature increase seems to be confirmed by the case of Morskie Oko. In 1973-2012 an increase in surface water temperature was observed $\left(0.4^{\circ} \mathrm{C} \cdot \mathrm{dec}^{-1}\right)$. The lake water temperature has risen particularly since the 1990 s and has never been lower than the multiannual average $\left(5.11^{\circ} \mathrm{C}\right)$.

4. The further increase in heat accumulated in the lake may alter the course of physico-chemical processes as well as biotic conditions. This investigation indicates that alpine lakes (commonly regarded as cool) may be an inexpensive source of clean energy - particularly useful in hard-to-reach terrain not affected by anthropopression.
5. Single thermal measurements of Morskie Oko lake waters indicate that the heat given back from rocks covering the lake bottom should be further investigated.

\section{References}

1. KOPÁČEK J., STUCHLÍK E., WRIGHT R.F. Long-term trends and spatial variability in nitrate leaching from alpine catchment-lake ecosystems in the Tatra Mountains (Slovakia-Poland). Environ. Pollut., 136, (1), 89, 2005.

2. GĄSIOROWSKI M., SIENKIEWICZ E. $20^{\text {th }}$ century acidification and warming as recorded in two alpine lakes in the Tatra Mountains (South Poland, Europe). Sci. Total Environ., 408, (5), 1091, 2010.

3. BACELA-SPYCHALSKA K., GRABOWSKI M., REWICZ T., KONOPACKA A., WATTIER R. The 'killer Shrimp' dikerogammarus villosus (crustacea, amphipoda) invading alpine lakes: Overland transport by recreational boats and scuba-diving gear as potential entry vectors? Aquatic Conserv., 23, (4), 606, 2013.

4. KABAŁA C., BOJKO O. Trends in trace element concentrations in holocene bottom sediments of a lake Wielki Staw in the Karkonosze Mountains. Pol. J. Environ. Stud., 23, (2), 357, 2014.

5. SIENKIEWICZ E., GĄSIOROWSKI M. Changes in the trophic status of three mountain lakes - Natural or anthropogenic process? Pol. J. Environ. Stud., 23, (3), 875, 2014. 
6. VERBURG P., HECKY R.E., KLING H. Ecological Consequences of a Century of Warming in Lake Tanganika, Science, 301, 505, 2003.

7. COATS R., J. PEREZ-LOSADA G. SCHLADOW R. RICHARDS, GOLDMAN C. The warming of Lake Tahoe. Clim. Change, 76, 121, 2006.

8. KELLER W. Implications of climate warming for Boreal Shield lakes: A review and synthesis. Environmental Reviews, 15, (1), 99, 2007.

9. WRZESIŃSKI D., CHOIŃSKI A., PTAK M. Effect of the North Atlantic Oscillation on the thermal characteristics of lakes in Poland. Acta Geophysica, 63, (3), 863, 2015.

10. THOMPSON R., KAMENIK C., SCHMIDT R. Ultra-sensitive Alpine lakes and climate change. Journal of Limnology, 64, (2), 139, 2005.

11. JONES I., GEORGE G., REYNOLDS C. Quantifying effects of phytoplankton on the heat budgets of two large limnetic enclosures. Freshwater Biol., 50, 1239, 2005.

12. THOMPSON R., VENTURA M., CAMARERO L. On the climate and weather of mountain and sub-arctic lakes in Europe and their susceptibility to future climate change. Freshwater Biol., 54, 2433, 2009.

13. GILLET C., P. QUETIN. Effect of temperature changes on the reproductive cycle of roach in Lake Geneva from 1983 to 2001. J. Fish Biol. 69, 518, 2006.

14. JEPPESEN E., MEHNER T., WINFIELD I.J., KANGUR K., SARVALA J., GERDEAUX D., RASK M., MALMQUIST H.J., HOLMGREN K., VOLTA P., ROMO S., ECKMANN R., SANDSTRÖM A., BLANCO S., KANGUR A., RAGNARSSON STABO H., TARVAINEN M., VENTELÄ A.-M., SØNDERGAARD M., LAURIDSEN T.L., MEERHOFF M. Impacts of climate warming on the long-term dynamics of key fish species in 24 European lakes (Review), Hydrobiologia, 694, (1), 1, 2012.

15. CHOIŃSKI A., PTAK M., STRZELCZAK A. Areal variation in ice cover thickness on lake Morskie Oko (Tatra Mountains). Carpathian Journal of Earth and Environmental Sciences, 8, (3), 97, 2013

16. CHOIŃSKI A., STRZELCZAK A. Bathymetric measurements of Morskie Oko Lake. Limnological Review, 11, (2), 89, 2011.

17. CHOIŃSKI A. Physical limnology of Poland, Wydawnictwo Naukowe UAM, Poznań, 2007 [In Polish].

18. ESCOBAR J., BUCK D.G., BRENNER M., CURTIS J.H., HOYOS N. Thermal stratification, mixing, and heat budgets of Florida lakes. Fundamental and Applied Limnology, 174, (4), 283, 2009.

19. KOSSMANN M., STURMAN A.P., ZAWAR-REZA P., MCGOWAN H.A., OLIPHANT A.J., OWENS I.F., SPRONKEN-SMITH R.A. Analysis of the wind field and heat budget in an alpine lake basin during summertime fair weather conditions. Meteorol. Atmos. Phys., 81, (1-2), 27, 2002.
20. LIVINGSTONE D. M., LOTTER A. E., WALKER I. R. The decrease in summer surface temperature with altitude in Swiss alpine lakes:a comparison with air temperature lapse rates. Arct. Antarct. Alp. Res., 31, 341, 1999.

21. LANGE W. Conditions influencing the accumulation of heat in lakes of the Kaszubskie Lakeland. Zesz., Nauk., UG, Geografia, 8, 1977 [In Polish].

22. OKULANIS E. Limnological study of RaduńskoOstrzyckie Lakes, Gdańskie Towarzystwo naukowe, Wydz. Nauk o Ziemi, V, Gdańsk, 1981 [In Polish].

23. LIVINGSTONE D.M., IMBODEN D.M. Annual heat balance and equilibrium temperature of Lake Aegeri, Switzerland. Aquat. Sci. 51/4, 351, 1989.

24. SAHOO G.B., SCHLADOW S.G. Estimation of Heat and Hydrologic Budget of Upper Klamath Lake Oregon, USA Using Updated DLM-WQ Model. Water Resour. Manag., 28, (5), 1395, 2014.

25. KANIKOWSKI J. Distribution of water temperature in Zamkowe Lake in Wałcz as the basis for the assessment of heat energy use, Poznań [PhD thesis], 1997 [In Polish].

26. ADRIAN R., O'REILLY C. M., ZAGARESE H., BAINES S. B., HESSEN D. O., KELLER W., LIVINGSTONE D. M., SOMMARUGA R., STRAILE D., VAN DONK E., WEYHENMEYER G.A., WINDER M. Lakes as sentinels of climate change. Limnol. Oceanogr., 54, 6, (2), 2283, 2009.

27. PARKER B.R., VINEBROOKE R.D., SCHINDLER D.W. Recent climate extremes alter alpine lake ecosystems, PNAS, 105, (35), 12927, 2008.

28. STAINSBY E.A., WINTER J.G., JARJANAZI H., PATERSON A.M., EVANS D.O., YOUNG J.D. Changes in the thermal stability of Lake Simcoe from 1980 to 2008. J. Great Lakes Res., 37, (Supl. 3), 55, 2011.

29. POCIASK-KARTECZKA J., CHOIŃSKI A. Recent trends in ice cover duration for Lake Morskie Oko (Tatra Mountains, East-Central Europe). Hydrology Research, 43, (4), 500, 2012.

30. JAKKILA J., LEPPÄRANTA M., KAWAMURA T., SHIRASAWA K., SALONEN K. Radiation transfer and heat budget during the ice season in Lake Pääärvi, Finland. Aquatic Ecology, 43, (3), 681, 2009.

31. MOMII K., ITO Y. Heat budget estimates for Lake Ikeda, Japan. J. Hydrol., 361, (3-4), 362, 2008

32. CHOIŃSKI A., HEESE T., OBERSKI T. The infrared camera: a tool for mountain lakes research, Limnological Review 13, (3), 129, 2013

33. NOVIKMEC M., SVITOK M., KOČICKÝ D., ŠPORKA F., BITUŠÍK P. Surface Water Temperature and Ice Cover of Tatra Mountains Lakes Depend on Altitude, Topographic Shading, and Bathymetry. Arct. Antarct. Alp. Res., 45, (1), 77, 2013.

34. LUOTO T.P., NEVALAINEN L. Long-term water temperature reconstructions from mountain lakes with different catchment and morphometric features. Scientific Reports, 3, art. no. 2488 , 2013. DOI: $10.1038 /$ srep02488 
